\title{
SIRKULASI DAN PENGEDARAN MAJALAH MELAYU SEBELUM PERANG DUNIA KEDUA
}

\author{
Hamedi Mohd Adnan
}

\begin{abstract}
For a magazine to survive in the market, three elements must be strengthened-the editorial content, circulation or distribution, and income from advertisement. The editorial content is responsible for attracting readers and thus will improve circulation. Increased circulation also often results in increased revenue from advertising. Thus, these three pillars, namely editorial, circulation, and advertising are very important for the survival of a magazine. Circulation refers to the number of copies sold to the readers. A good magazine circulation depends on the efficiency and effectiveness of marketing techniques, as well as the efficiency of distribution system used by the publisher to deliver the magazine to the reader. The publishers of Malay magazines after the Second World War were entirely dependent on circulation of the magazine to cover expenses and to expect profit. This article discusses the circulation and distribution practices of Malay magazines published before the war and its impact on magazines in the market.
\end{abstract}

\section{Pengenalan}

Secara umumnya lebih 120 buah majalah telah diterbitkan dalam bahasa Melayu sehingga meletusnya Perang Dunia Kedua pada Disember 1941. Pada masa yang sama lebih 50 buah akhbar diterbitkan. Jumlah penerbitan tempoh ini dapat dianggap tinggi memandangkan kadar celik huruf yang masih rendah dalam kalangan masyarakat Melayu ketika itu. Penerbitan Melayu dalam tempoh ini lebih tertumpu di dua buah negeri Selat iaitu Singapura dan Pulau Pinang. Sejumlah 74 buah 
majalah diterbitkan di kedua-dua kota dengan 45 buah di Singapura dan 29 buah di Pulau Pinang. Sehingga 1918, tiada sebuah pun penerbitan diterbitkan di Semenanjung dengan kesemuanya iaitu 11 buah akhbar dan dua buah majalah diterbitkan di kedua-dua buah Negeri Selat itu.

Semua penerbitan ini memberikan sumbangan yang pelbagai. Akhbar dan majalah ini menyediakan bahan bacaan yang dapat meluaskan pengetahuan pembaca terhadap alam sekeliling mereka. Penerbit atau pengarangnya juga mengambil kesempatan dengan memberikan ingatan, amaran, rangsangan, dan kadangkala sindiran supaya orang Melayu menyingsing lengan dan mengubah tabiat, dan menggesa supaya gejala buruk mereka diubah. Soal peranan majalah atau akhbar kepada masyarakat Melayu sering diulang-ulang, baik dalam bentuk artikel atau syair. Semuanya bertujuan supaya mereka tidak terus ketinggalan berbanding dengan masyarakat lain, terutamanya golongan pendatang.

Dalam perusahaan majalah Melayu sebelum Perang Dunia Kedua, penerbit bergantung sepenuhnya pada sirkulasi atau jualan naskhah untuk memperoleh pendapatan. Artikel ini akan membincangkan situasi sirkulasi majalah Melayu dalam tempoh sebelum perang iaitu dari 1900 hingga 1941. Maklumat tentang sirkulasi diperoleh daripada laporan FMS Government Gazette dan Straits Settlements Government Gazette di samping data daripada Blue Book yang dipetik daripada Proudfoot.

\section{Penerbitan Majalah Melayu}

Penerbit majalah Melayu sebelum perang bergantung sepenuhnya pada sirkulasi majalah untuk menampung perbelanjaan penerbitan dan mengharapkan untung. Walau bagaimanapun pelbagai masalah terpaksa dihadapi penerbit dalam soal ini. Paling asas ialah rendahnya potensi pembaca yang ada. Pengasoh menyatakan:

Tiada seorang daripada bangsa Melayu yang suka membaca surat2 khabar ialah kerana mereka itu tiada tahu atau belum belajar menulis dan membaca. Maka jikalau ada yang tahu membaca sekalipun akan tetapinya pada tentang membaca surat 2 khabar itu disifatkan dia suatu perkara yang tiada memberi faedah kepada mereka itu. ${ }^{1}$

Muhammad Dato' Muda, editor Mujallah Guru pula menyatakan:

Dan lagi hendaklah diingat! Penduduk Semenanjung ini bukanlah ramai. Dua setengah milion Melayu, itu bukan semuanya atau separuhnya atau sesukunya yang tahu membaca kerana bilangan itu termasuk sekali yang buta (buta mata, buta perut, dan buta kayu) yang tuli, yang tempang, yang tiada bersekolah, dan kanak2. Maka 
daripada yang tahu membaca itu berapa pula yang pandainya dan daripada yang pandai membaca itu berapa orang yang gemarnya dan daripada yang gemar membaca itu berapa orang yang suka membeli atau berlanggan dengan surat2 khabar atau majalah dan daripada yang suka membeli itu berapa kerat yang mampu? Kiralah sendiri. $^{2}$

Anggaran yang dibuat oleh pengarang Dunia Akhirat mungkin realistik bagi menggambarkan jumlah sebenar potensi pembaca yang ada ketika itu. Menurut pengarang:

Orang yang suka membaca majalah dan surat-surat khabar Melayu dalam Malaya ini hanya lebih kurang 5,000 orang termasuk sekali di dalamnya orang-orang yang masih di bangku pelajaran. Kebanyakan daripada orang ini ialah pegawai-pegawai kerajaan, orang yang memakan gaji kepada saudagar-saudagar, guru-guru agama, dan sedikit daripadanya orang kebun dan saudagar-saudagar. Dan sejumlah besar daripada pembaca-pembaca itu orang yang berpengetahuan. ${ }^{3}$

Petikan di atas menjelaskan jumlah pasaran bagi bahan penerbitan seperti buku, majalah atau akhbar di Tanah Melayu amat terbatas. Namun kadar celik huruf telah semakin meningkat. Banci yang dibuat oleh pihak British menunjukkan bahawa kira-kira 30 peratus orang Melayu "able to read and write a letter." dan Melaka kadarnya ialah 25.4 peratus sementara kadar di bandarbandar terpilih Taiping 38.5 peratus dan Kota Bharu, Johor Bahru, bandar Maharani, Ipoh, Kampar, Klang, Kuala Lumpur, Seremban, Taiping dan Teluk Anson masing-masing 12.3 peratus. Pada tahun 1931, peratusan orang Melayu yang kenal huruf di Negeri-Negeri Selat ialah 42.8 peratus, 42.5 peratus di Negeri-Negeri Melayu Bersekutu, dan 34.5 peratus di Negeri-Negeri Melayu Tak Bersekutu. ${ }^{5}$

Peningkatan kadar celik huruf adalah berikutan meningkatnya bilangan sekolah, khususnya pada dekad 30-an. Namun purata peningkatan tersebut tidak memberikan kesan yang signifikan terhadap pembacaan majalah. Memanglah kadar sirkulasi majalah atau akhbar semakin meningkat daripada purata 500 naskhah pada dekad pertama kepada 700 naskhah dekad 20-an dan kemudian 1,000 naskhah pada dekad 30-an. Namun, kadar peningkatannya tidak selaras dengan pertambahan kadar celik huruf yang ada. Sebagai contoh yang khusus, Mujallah Guru mula-mula diedarkan sebanyak 250 naskhah (1924) sebelum meningkat kepada 600 naskhah (1925) dan kepada 1,000 naskhah (1932). ${ }^{6}$ Pada 1932, sirkulasi majalah itu hanya diatasi oleh akhbar Majlis yang mempunyai sirkulasi 2,000 naskhah. Walau 
bagaimanapun jika majalah di Negeri-negeri Selat turut diambil kira, sirkulasi Mujallah Guru tidaklah terlalu besar kerana majalah seperti Idaran Zaman dan Semangat Islam mempunyai lebih 1,000 naskhah. ${ }^{7}$

Pada umumnya amalan membaca masih dilihat sebagai aktivti masa lapang untuk golongan yang berkemampuan dan berpendidkan. Tahap pendidikan yang umumnya masih rendah dan kemiskinan hidup menjadikan amalan membaca tidak menjadi keutamaan masyarakat Melayu pada period sebelum perang. Dengan situasi yang demikian sirkulasi atau pengedaran bahan bacaan menerusi pasaran terbuka seperti majalah dapat dijangka menghadapi masalah.

\section{Sirkulasi Majalah Melayu Sebelum Perang}

Soal sirkulasi majalah Melayu tidak banyak menarik perhatian untuk dikaji. Hal ini terutamanya disebabkan sumber data yang merekodkan hal ini bukan sahaja terbatas, tetapi juga sering mengelirukan. Sumber yang paling berwibawa yang lazimnya digunakan oleh para pengkaji ialah maklumat yang tercatat dalam Blue Book bagi majalah atau akhbar yang diterbitkan di Negeri-negeri Selat atau gazet kerajaan bagi yang diterbitkan di Negeri-negeri Melayu Bersekutu. Malangnya, tidak semua penerbitan direkodkan dalam kedua-dua sumber itu. Penguatkuasaan pada waktu itu tidak ketat apatah lagi jika sesuatu penerbitan itu tidak kelihatan boleh menimbulkan masalah dari segi politik. Justeru, daripada 120 buah majalah Melayu yang diterbitkan pada zaman sebelum Perang Dunia Kedua, hanya 15 yang mempunyai rekod dalam Blue Book. ${ }^{8}$

Data yang dikemukakan juga sering mengelirukan, khususnya yang berkait dengan istilah "sirkulasi" atau "jumlah cetakan". Kebanyakan majalah merekodkan jumlah naskhah yang dicetak sebagai sirkulasi dalam Blue Book, sedangkan dalam pengertian sebenar sirkulasi merupakan jumlah naskhah yang laku dijual dalam sesuatu tempoh perekodan. ${ }^{9}$

Secara puratanya, sirkulasi untuk majalah Melayu sebelum perang ialah 400 naskhah sebelum dekad 20-an dan meningkat kepada 1,000 naskhah mulai dekad 30-an, iaitu apabila majalah sudah bersifat nasional. Sementara itu, terdapat majalah yang edarannya terbatas di kawasan tertentu atau dalam kalangan pembaca tertentu dalam pertubuhan atau persatuan tertentu. Rata-rata majalah yang terbit di Singapura dapat diperoleh di kedai-kedai buku utama di Kota Bharu dan Alor Setar. Antara kedai buku utama pada zaman sebelum Perang ialah Hj. Muhammad Siraj ${ }^{10}$, Hasyim Abdullah, dan Dulfakir \& Co. di Singapura, Federal Rubber Stamp di Kuala Lumpur dan cawangannya di Pulau Pinang dan Matbaah Az-Ziniah di Pulau Pinang. Kedai-kedai 
buku tersebut bukan sahaja menjual buku dan majalah secara runcit malahan menjadi pengedar atau wakil tunggal kebanyakan akhbar dan majalah Melayu.

Rekod-rekod yang diperoleh dari FMS Government Gazette dan Straits Settlements Government Gazette serba sedikit memberikan penjelasan tentang jumlah sirkulasi majalah Melayu. Memandangkan terdapat majalah Melayu yang tidak berdaftar di bawah Publishing and Book Enactment 1915, maka semua maklumat sirkulasi 120 majalah Melayu yang diterbitkan sebelum Perang tidak dapat diperoleh. Hanya 66 buah majalah yang berdaftar di kedua-dua gazet dapat dikesan misalnya al-Imam dengan 5,000 naskhah ${ }^{11}$ dan yang paling sedikit sirkulasinya pula Tetauan Muda iaitu sebanyak 100 naskhah. Majalah yang penting sebelum perang dengan sirkulasinya adalah seperti yang berikut: al-Ikhwan (2,000 naskhah), Kahidupan Dunia Akhirat (3,000 naskhah), Dunia Sekarang (2,000 naskhah), Chahaya Singapura (1,000 naskhah), Mustika (2,000 naskhah), Kemajuan Melayu (1,000 naskhah), Mujallah Guru (1,000 naskhah), Majallah Pemuda (1,000 naskhah), Lidah Ibu (1,300 naskhah), Semangat Islam (1,000 naskhah), Dunia Melayu (750 naskhah) dan Ar-Raja (500 naskhah).

\section{Sistem Pengedaran Majalah}

Sistem pemasaran penerbit lazimnya terbahagi dua, iaitu jualan terus kepada orang ramai melalui sistem langganannya dan yang paling penting hubungan dagang antara penerbit dengan kedai-kedai buku yang dipilih. ${ }^{12}$ Kadar langganan dalam kalangan pembaca amat terbatas ${ }^{13}$ walaupun kadar bayaran pos ketika itu tidaklah begitu tinggi. Kadar bayaran penghantaran untuk majalah atau surat khabar pada 1938 ialah 2 sen untuk 2 ouns dan 2 sen lagi untuk tambahan setiap 5 ouns. Untuk bungkusan pula kadarnya ialah 30 sen untuk tidak melebihi tiga paun, 50 sen tidak lebih tujuh paun, 70 sen tidak lebih sebelas paun, dan RM1.10 untuk tidak lebih 22 paun. ${ }^{14}$

Dalam sistem langganan ini, orang ramai yang berminat menjadi pelanggan dikehendaki membayar kepada penerbit terlebih dahulu ${ }^{15}$ akan nilai majalah dalam tempoh langganan yang dipilihnya sama ada tiga bulan, enam bulan, atau dua belas bulan. Wang itu akan menjadi deposit pelanggan kepada penerbit. Mujallah Al-Riwayat, umpamanya menyatakan:

Wang harga langganan bagi setahun dan enam bulan itu akan dikeluarkan resit sebagai wang deposit dan apakala telah dihantar naskhah-naskhah Mujallah Al-Riwayat kepada empunya wang itu kadar mencukupi sebanyak wang yang didepositkan itu, baharulah 
dikeluarkan resit harganya. Sekiranya tuan empunya wang hendak menarik langganan bila-bila masa jua, maka sesungguhnya sedia Al-Maarif mengembalikan wang yang baki daripada langganan, meskipun sedikit tetapi wang! ${ }^{16}$

Sistem langganan ini, jika berjalan dengan lancar akan lebih menguntungkan penerbit kerana mereka tidak perlu memberi diskaun yang tinggi berbanding jika mereka bergantung pada ejen atau wakil penjual yang lazimnya diberi potongan harga 20-30 peratus daripada harga majalah. Namun kadang-kadang harga langganan boleh dikurangkan kepada pembaca tertentu. Ar-Raja umpamanya memberikan potongan harga yang istimewa kepada murid-murid sekolah dengan harga langganan RM2.50 setahun (kadar biasa RM3.75) dan RM1.50 untuk enam bulan (kadar biasa RM1.90). Bagaimanapun, murid-murid sekolah hendaklah mengirimkan wang langganannya terus kepada penerbit dan tidak perlu melalui wakil penjual. ${ }^{17}$ Cara pembayaran harga langganan dibuat dengan beberapa cara sehingga kadangkala mengelirukan dan hal ini memerlukan penjelasan daripada penerbitnya.

Antara majalah yang sering mengingatkan pelanggannya akan cara membuat pembayaran langganan ialah al-Hedayah. Umpamanya pada Ogos 1923, para pelanggan dinasihatkan bahawa:

Bahawa semudah-mudah dan sederas-deras sampai mengirim harga langganan itu dimasukkan wang berserta dengan surat ke dalam sampul serta disealkan di atas sampul itu, kemudian register surat itu kepada pengedar pemancar (majalah) kerana kirim dengan order itu lambat sampai sehingga dua bulan tiada dapat diterima lagi. ${ }^{18}$

Pada bulan berikutnya, al-Hedayah sekali lagi mengingatkan pelanggannya:

Dengan sebesar-besar harapan kita jikalau hendak membayar langganan $\mathrm{Al}$-Hedayah memadalah kirimkan dengan dimasukkan wangnya ke dalam sampul register serta materikan dengan seal di lidahnya kerana kiriman dengan money order itu melambatkan dan menyusahkan kita dan juga harganya itu tersangat sedikit. Kita tiadalah terima bayaran dengan cek bank dikecualikan ditambah wang komisen bank itu pada tiap-tiap RM3.50 hendaklah ditambah 82 sen. $^{19}$

Penjualan secara langganan terus kepada pembaca sesungguhnya menguntungkan penerbit dengan tiga cara. Pertama, penerbit akan memperoleh bayaran langganan terlebih dahulu daripada pelanggan dan wang itu dapat digunakan sebagai modal pusingan untuk 
menerbitkan majalah. Dengan mempunyai jumlah langganan yang banyak dan dalam jangka masa yang panjang pula umpamanya setahun, jumlah modal pusingan yang diperoleh penerbit menjadi lebih besar dan ia dapat merancang penerbitan majalahnya dengan lebih baik. Kedua, penerbit tidak perlu memberikan potongan harga kepada wakil penjual atau pengedar dengan langganan terus. Meskipun sesetengah penerbit masih memberikan potongan harga kepada pelanggan terus namun jumlahnya jauh lebih kurang daripada potongan harga yang terpaksa diberi kepada peniaga jika penerbit menggunakan mereka dalam saluran pengedaran majalahnya. Ketiga pula, kadar atau jumlah langganan akan menjadi indikator kepada penerbit tentang jumlah naskhah yang perlu dicetak dalam sesuatu keluaran. Disebabkan jumlah langganan ini menjadi pembeli yang pasti, penerbit dapat membuat anggaran yang lebih realisitik dan risiko naskhah-naskhah tidak terjual dapat dikurangkan.

Namun demikian, pengurusan langganan terus kadangkala terlalu remeh dan menjadi beban tambahan kepada penerbit. Tugas-tugas membuat promosi untuk langganan, pemprosesan, penerimaan dan perekodan bayaran, pengemaskinian rekod langganan, penghantaran, dan sebagainya sering menyebabkan tumpuan penerbit dan juga pengarang teralih kepada kerja-kerja yang remeh-temeh ini. Akibatnya tumpuan penuh tidak dapat diberikan kepada majalah apatah lagi memandangkan saiz penerbit majalah sebelum perang amat kecil. Dalam kes Malaya umpamanya, Mohd Yunus Abdul Hamid menjalankan pelbagai kerja misalnya sebagai pengarang, pengurus, kerani, tambi dan lain-lain. ${ }^{20}$ Begitu juga halnya dengan pengarang Mujallah Guru yang pertama iaitu Muhamad Dato' Muda yang menguruskan penerbitan majalah itu secara bersendirian sehingga beliau berasa kecewa dengan kritikan daripada pembaca tentang gaya kepengarangannya. Beliau menyatakan:

... guru inilah yang menjadi pengarang, pengurus, kerani yang mengedarkan majalah dan lain-lain. Dia harus terpaksa menghadapi banyak masalah dengan pencetak, dengan masalah kurang kertas, mesin cetak rosak, penjalan mesin cetak berhenti kerja, semua ini dia terpaksa mengatasinya. ${ }^{21}$

Dengan struktur organisasi penerbit yang ringkas kerana bilangan kakitangan yang sedikit, tugas pengarang lazimnya terganggu dengan urusan-urusan langganan. Untuk mengurangkan kos, terdapat majalah umpamanya Dunia Sekarang yang tidak menerima sebarang langganan yang kurang daripada setahun. 


\section{Wakil Penjual Sebagai Penyalur Majalah}

Saluran pengedaran yang juga penting ialah ejen penjual yang lazimnya terdiri daripada kedai buku di bandar besar. Mengikut amalan yang lazim, penerbit akan mendapatkan pesanan daripada ejen. Mereka akan mengemukakan tawaran kepada para penjual yang mahu mengedarkan majalahnya. Royal Publishing Company, Singapura yang menerbitkan beberapa buah majalah seperti Medan Laki-Laki dan Medan al-Islam dan akhbar seperti Shorga Dunia, Melayu Muda, dan Dunia Sekarang umpamanya mengiklankan:

Wanted! Agents in every town and village throughout Malaya to sell our books, magazines, and newspapers to the Malays. With a capital of RM10.00 you can easily earn RM15.00 to RM20.00 every month in your spare time. ${ }^{22}$

Secara spesifik, Dunia Sekarang, 28 Julai 1934 menyatakan:

Dunia Sekarang ini sangat laku dijual di merata-rata tempat masingmasing berebut-rebut membeli akan dia hingga tidak pernah yang cukup pada tiap-tiap kali keluarnya. Dari sebab itu jika tuan menjadi wakil DS ini di tempat tuan senang-senang tuan boleh mendapat untung daripadanya pada tiap-tiap bulan. Beratus-ratus naskhah ada dijual pada satu-satu tempat. ${ }^{23}$

Kebanyakan penerbit menggunakan ejen sebagai wakil penjual dan bukan wakil tunggal melainkan majalah Tanah Melayu (Mac 1933) yang menggunakan sistem tersebut. ${ }^{24}$ Majalah itu dalam keluarannya pada 29 Januari 1934 menyebut:

Notice is hereby given that I have this day appointed S.A. Ibrahim Ghunny $\mathcal{E}$ Co., of No. 16, Queen Street, Singapore as my sole agent for the Tanah Melayu magazine. In future copies of the Tanah Melayu will be distributed throughout Malaya by S.A. Ibrahim Ghunny \& Co, who will also dispatch the magazine every month to subscribers and sub-agents in Singapore and out stations. All payments for subscriptions, advertisements, sale of the magazines, etc., must be paid to S.A. Ibrahim Ghunny \& Co., and not to any other person. Newsagents, advertisers and subscribers throughout Malaya are kindly requested to deal direct with S.A. Ibrahim Ghunny \& Co. only. ${ }^{25}$

Kelebihan utama menggunakan wakil penjual ialah penerbit tidak terlalu bergantung pada satu-satu peniaga sahaja (dalam kes wakil tunggal). Ini bermakna bahawa jika sebuah wakil penjual menimbulkan masalah umpamanya tidak cekap atau tidak membuat pembayaran apabila tiba masanya, penerbit masih dapat berharap kepada wakil penjual yang lain. Dengan demikian modal pusingan penerbit sentiasa 
ada kerana sementara satu atau dua wakil penjual mungkin bermasalah, yang lain masih dapat diharap untuk menjalankan tugasnya dengan baik. Namun risikonya, penerbit mungkin terpaksa berurusan dengan terlalu banyak wakil penjual sehingga meningkatkan perbelanjaannya.

Penggunaan wakil tunggal dapat memudahkan penerbit mengawal penjualan majalahnya. Mereka hanya berurusan dengan satu pihak sahaja dan urusan pengutipan bayaran akan menjadi tanggungjawab wakil tunggal. Wakil tunggal lazimnya mampu memainkan peranannya sebagai pengedar majalah dengan lebih cekap daripada penerbit, dan juga berupaya mengutip bayaran majalah daripada ejen dengan lebih berkesan. Salah sebuah wakil tunggal yang penting pada tahun 1930-an, S.A. Ibrahim Ghunny \& Co. yang beroperasi di Queen Street, Singapura membuat pelbagai notis kepada ejen supaya menjelaskan bayaran majalah masing-masing. Antaranya dinyatakan:

Dengan ini kita beritahu sekiranya wang harga keluaran-keluaran bulan yang lalu itu tidak dikirim kepada kita dengan segera, terpaksalah kita datang sendiri ke tempat tuan dalam sedikit masa lagi kerana memungut wang itu dari tuan. Pada masa itu terpaksalah pula kita menuntut perbelanjaan kita datang ke tempat tuan itu. Oleh sebab iaitu kelak menjadi satu kerugian kepada tuan, kita fikir terlebih baik tuan kirim mari dengan segera wang itu kepada kita dengan money order atau register seperti biasa. Inilah diberitahu terlebih dahulu daripada berlaku apa-apa hal. ${ }^{26}$

Namun keburukannya ialah seandainya wakil penjual menimbulkan masalah, umpamanya lewat membuat pembayaran, penerbit tidak dapat mengharapkan pihak lain lagi untuk memperoleh modal pusingan. Atas alasan itu, penggunaan wakil penjual dalam kalangan penerbit adalah suatu kelaziman. Kebanyakan majalah akan memaparkan nama wakil penjualnya di halaman majalah masingmasing dan disebabkan terhadnya bilangan penjual buku ketika itu, maka sudah tentu pertindanan sering berlaku misalnya sesebuah kedai buku menjadi wakil penjual kepada banyak majalah. Antara kedai buku utama yang menjadi wakil penjual untuk banyak majalah sebelum perang adalah seperti dalam senarai di bawah.

Terdapat juga dalam kalangan wakil penjual ini merupakan orang perseorangan atau pegawai kerajaan. Mereka biasanya merupakan individu yang berminat dalam pembacaan atau tulis-menulis serta mempunyai rakan atau kenalan yang berminat dalam bidang yang sama. Antara mereka ialah Muhammad Nuruddin, guru besar sekolah Melayu Tapah yang menjadi wakil penjual Ar-Raja, Abbas Hj. Ali iaitu guru sekolah Melayu Temiang, Seremban (al-Ikhwan); Mohd Hasyim (Pejabat Pelajaran Taiping-(Mujallah Guru); Abdul Samad Tahir, 


\section{Jadual 1: Senarai Wakil Penjual Utama Sebelum Perang}

\begin{tabular}{|l|l|}
\hline NAMA PENIAGA/WAKIL PENJUAL & \multicolumn{1}{l|}{ NEGERI/BANDAR } \\
\hline Hj. Muhamad Siraj & Bussorah Street, Singapura \\
\hline B. Sulaiman; Hasyim Abdullah & Arab Street, Singapura \\
\hline K.A. Fakir Mohammad & Keppel Road, Singapura \\
\hline R.K. Samy \& Co. & Changi Road, Singapura \\
\hline S. Mohammad Kassim & Kallang Road, Singapura \\
\hline Dulfakir \& Co. & North Bridge Road Singapura \\
\hline $\begin{array}{l}\text { M.M. Dulfakir \& Co.; Federal Rubber } \\
\text { Stamp; Zainuddin \& Co. }\end{array}$ & Kuala Lumpur \\
\hline $\begin{array}{l}\text { Muhd Hj. AbdulSalam \& Co.; Hj. Abdullah } \\
\text { Fakeh }\end{array}$ & Melaka \\
\hline $\begin{array}{l}\text { Matbaah Al-Mansuriah; Wan Mohd Taib } \\
\text { Lembong; A.S. Kechik }\end{array}$ & Alor Setar \\
\hline Muhammad Din; Matbaah Az-Ziniah & Taiping; \\
\hline Alwi \& Co.; Shah Hamid \& Co. & Tanjung Malim \\
\hline D.Y. Brothers & Kota Bharu \\
\hline Central Store; Sahil \& Co. di & Johor Bahru; \\
\hline Yahya \& Co.; Abu Bakar \& Co. & Ipoh; \\
\hline Bahnan \& Co.; Rahman \& Co.; A.M. Talib & Muar \\
\hline Hj. Muhammad Said & Yan, Kedah \\
\hline Sipi Bombay Store & Batu Pahat \\
\hline Syed Salim \& Co.; Uniport \& Co. & Kajang \\
\hline $\begin{array}{l}\text { S.O. Abd Wahab \& Co.; Federal Rubber } \\
\text { Stamp; Abbas Hj. Ali }\end{array}$ & Seremban \\
\hline $\begin{array}{l}\text { Matbaah Az-Ziniah; Hj. Abdullah } \\
\text { Nuruddin; Federal Rubber Stamp }\end{array}$ & Pulau Pinang. \\
\hline
\end{tabular}

Sumber: Hamedi M. Adnan, Majalah Melayu Sebelum Perang Dunia Kedua, Tanjung Malim: Institut Peradaban Melayu, 2014, hlm. 23.

guru Sekolah Melayu Kampung Tengah, Kuala Pilah (Tetauan Muda); Muhammad Pilus Ismail (Pejabat Tanah, Tampin-Tetauan Muda); Ahmad Mohd Taib, (Sekolah Melayu Pontian-al-Ikhwan); Abdul Manaf, Siak Masjid Batu Gajah (Bulan Melayu); Ahmad Lazim Bokhir dan Tuan Hj Ali, kedua-duanya guru di Batu Pahat (Masa); dan Tuan Hj Muhamad Said, Yan (Tetauan Muda). ${ }^{27}$

Selain itu, kelancaran urus niaga seperti ini sering terjejas, terutama jika penerbit berurusan dengan ejen yang baru membuka kedai buku atau penerbit sendiri yang kurang arif tentang urus niaga penjualan majalah. Soal siapa yang harus menanggung kos penghantaran 
majalah sering ditimbulkan oleh penerbit misalnya majalah Jasa sering mengingatkan ejen-ejennya supaya mengirimkan wang langganan menerusi register atau money order dan tidak mengirimkan setem sebagai ganti pembayaran. ${ }^{28}$

Untuk melindungi urus niaga majalahnya daripada sebarang risiko, sesetengah penerbit mensyaratkan wakil tunggal membayar deposit walaupun kebanyakan mereka lebih bersedia menanggung risiko majalahnya tidak berbayar. Deposit ini menjadi cagaran wakil tunggal atau penjual kepada penerbit daripada sebarang risiko perniagaan, khususnya penipuan. Seandainya wakil penjual atau peniaga tidak membuat pembayaran akan nilai majalah yang diambilnya daripada penerbit pada waktu yang disetujui, penerbit akan mengambil deposit tersebut. Biasanya penerbit menghendaki ejen membayar wang cagaran terlebih dahulu sebelum mengambil sebarang naskhah majalah. Umpamanya Majalah Panduan menyatakan:

Barangsiapa hendak menjadi wakil kirimlah wang simpanan terlebih dahulu sebanyak RM5.00 supaya dapat kita kirimkan 25 kopi Panduan. Jika berkehendak bilangan Panduan lebih daripada 25 kopi wang simpanan pun menurut berat jua. ${ }^{29}$

Nilai wang jaminan yang ditetapkan penerbit berbeza-beza nilainya antara sebuah majalah dengan majalah lain, dengan nilai antara RM5.00 hingga RM10.00. Terdapat juga majalah umpamanya Tanah Melayu yang menghendaki wakil tunggalnya menyediakan wang jaminan yang cukup banyak, iaitu RM200. ${ }^{30}$ Namun umumnya wang deposit yang ditetapkan agak rendah. Hanya apabila wang deposit itu dihantar kepada penerbit, barulah naskhah majalah dihantar kepada wakil penjual. Dunia Sekarang yang dijual dengan harga RM0.15 mensyaratkan ejen membayar RM3.00 terlebih dahulu. Wang deposit akan diambil oleh penerbit jika ejen tidak membuat bayaran, tetapi dikembalikan apabila wakil penjual berhenti daripada menjadi ejen. Menurut Dunia Sekarang:

Wang pendahuluan ini ialah sebagai akuan atau jaminan taruk dalam simpanan kita sahaja sebagai tanda ikhlas dan akan dikembalikan kepada tuan dengan secukup apabila tuan berhenti daripada menjadi ejen kita kelak. ${ }^{31}$

Jumlah naskhah majalah yang dicetak dalam satu-satu keluaran ditentukan daripada bilangan naskhah yang dipesan ini. Penerbit menghantar naskhah majalah yang dipesan kepada ejen-ejen melalui pos dan menanggung perbelanjaannya. Terdapat juga penerbit yang tidak menunggu pesanan daripada kedai terlebih dahulu, sebaliknya 
terus menghantar naskhah majalahnya kepada peniaga dengan harapan mereka akan membuat pesanan tambahan. Langkahan Baru umpamanya menghantar naskhah majalahnya terlebih dahulu walaupun belum mendapat persetujuan daripada peniaga untuk menjadi wakil penjualnya. Dinyatakan dalam Langkahan Baru umpamanya:

Bilangan 1 Langkahan Baru ini membawa cerita 'Hartawan Budiman.' Kami kirimkan naskhah-naskhah dengan maksud minta persetujuan: 1. Sukakah tuan menjadi ejen menjual di tempat tuan? 2. Kiranya tuan bersetuju, berilah kenyataan berapa kopi boleh laku di tempat tuan, iaitu menurut kira-kira harus. 3. Kiranya tidak bersetuju, tolong kirimkan semula naskhah-naskhah kepada kita. 4. Yang tidak laku atau habis masa dua bulan, harus dikirim kembali pada kita kiranya tidak dikirim kita kira sebagai laku dan wangnya harus dikirim. ${ }^{32}$

Untuk setiap naskhah majalah yang terjual, penerbit memberikan potongan harga sebanyak 20 hingga 30 peratus daripada harga jualan. Kadar potongan harga ini bergantung pada bilangan naskhah yang dapat dijual dan urus niaga antara penerbit dengan ejen dijalankan secara on-orders (pesanan) dan consignment (kirim jual). Untuk urus niaga secara pesanan, jika naskhah majalah tidak laku, ejen atau penjual tidak dibenarkan memulangkan semula kepada penerbit. Untuk kirim jual pula, ejen-ejen boleh memulangkannya semula kepada penerbit, tetapi mereka terpaksa menanggung kos penghantaran. Hal ini disebabkan bilangan naskhah untuk kirim jual ditentukan oleh ejen, bukannya penerbit. Bayaran harga majalah setelah ditolak potongan harga akan dibuat oleh ejen kepada penerbit sebulan sekali atau dua kali sebulan.

Bersama-sama bayaran itu, terdapat penerbit yang mensyaratkan penjual mengemukakan laporan jualan. Langkahan Baru menyatakan bahawa salah satu perjanjian dengan penjual ialah pada "tiap-tiap tanggal 5 hari bulan harus mengirim report bersama-sama wang yang laku." Dunia Sekarang pula menyatakan:

Syarat-syarat yang lain seperti biasa, iaitu kita beri $20 \%$ komisen kepada tuan sebagai upah tuan menjual akhbar/majalah itu. Yang tak laku hendaklah dikembalikan kepada kita pada akhir tiap-tiap bulan. Belanja kita mengirim kepada tuan di atas kita dan belanja tuan mengirim surat-surat, wang dan sebagainya kepada kita tertanggunglah di atas tuan sendiri. ${ }^{33}$

\section{Kesimpulan}

Penerbitan majalah Melayu sebelum Perang Dunia Kedua berkembang dengan perlahan misalnya dapat dilihat melalui jumlah pembacanya 
yang amat terbatas dengan purata edaran majalah sebelum perang hanyalah sekitar 500-700 naskhah. Sistem pendidikan yang membolehkan masyarakat celik huruf dan mampu merangsang pembacaan belum lagi meluas ketika itu. Hidup masyarakat Melayu pula dilatari kesukaran ekonomi dan keterbelakangan sosial. Dalam keadaan latar masyarakat sedemikian, amalan lazim dalam perusahaan penerbitan majalah tidak banyak membantu melepaskan perusahaan majalah daripada belenggu masalah.

Sistem pengedaran majalah terlalu bergantung pada langganan terus. Pengedaran menerusi ejen kedai buku tertumpu di bandar besar sahaja. Penerbit hanya bergantung pada ihsan penerbit lain untuk mempromosikan majalah terbitannya. Amalan promosi yang lazim ialah penerbit memberikan majalah percuma kepada penerbit majalah atau akhbar lain dengan harapan majalah itu dapat diulas dan disiarkan dalam penerbitan mereka. Dengan cara itu, khalayak pembaca dapat mengetahui kewujudan majalah tersebut.

Kedudukan dan jumlah pasaran yang kecil menyebabkan ekonomi penerbitan majalah tidak diberi penekanan oleh para penerbit. Dalam keadaan tertentu seperti dalam soal editorial dan pengeluaran, penerbit mungkin mencari formula yang dapat mengurangkan perbelanjaan, tetapi dalam soal pemasaran dan pensegmenan pembaca, pertimbangan yang serupa jarang diambil. Hal ini berlaku disebabkan para penerbit sendiri belum cukup menguasai bidang perniagaan bahan bercetak, di samping kegagalan mereka untuk memahami konsep pemasaran dengan lebih meluas. Apa yang ketara diberi perhatian ialah kandungan editorial majalah yang diterbitkan.

Tiga aspek lain yang seharusnya diberi penekanan yang sama dalam penerbitan majalah, iaitu promosi, peletakan harga majalah, dan pengedaran. Hal ini tidak menghairankan kerana ramai daripada pemodal dalam perusahaan penerbitan majalah atau akhbar ketika itu tidak mempunyai pengetahuan tentang jenis perniagaan ini. Walaupun pertimbangan itu mungkin dilakukan dalam sesetengah keadaan, namun atas alasan bahawa penglibatan mereka dalam penerbitan bukanlah untuk mencari keuntungan, maka soal ekonomi penerbitan diabaikan. Seperti juga halnya pada waktu ini, perusahaan penerbitan majalah sebelum perang tidak memberi pulangan yang lumayan kepada pengusahanya. Jumlah pembaca yang berupaya membeli majalah umumnya agak kecil dan ini menyebabkan perniagaan penerbitan majalah tidak menguntungkan walaupun modal yang diperuntukkan bagi perusahaan ini agak tinggi 


\section{Nota}

1 Pengasoh, 30 Julai 1920, hlm. 6.

2 Muhammad Dato' Muda, Mujallah Guru, 1938, hlm. 403.

3 Dunia Akhirat, 10 November 1936, hlm. 4.

4 J.E. Nathan, The Census of British Malaya: The Straits Settlements, Federated Malay States and Protected States of Johore, Kedah, Perlis, Kelantan, Terengganu and Brunei, London: Dunstalbe \& Watford, 1922, hlm. 18.

5 Ibid.

6 Butiran-butiran sirkulasi diperoleh daripada FMS Government Gazette, 1924 hingga 1932.

7 Lihat Hamedi Mohd Adnan, Direktori Majalah Melayu Sebelum Merdeka, Kuala Lumpur: penerbit Universiti Malaya, 2002, hlm. 87.

8 Ibid.

$9 \quad$ J. Wharton, Magazine Publishing, London: Blueprint, 1992, hlm. 16-28; Sammye Johnson \& Patricia Prijatel, Magazine: From Cover to Cover, Chicago: NTC Publishing Group,1998, hlm. 25-41.

10 Perniagaan buku Hj. Muhammad Siraj telah dimulakan pada akhir abad ke-19 lagi dan sehingga awal abad ke-20 kedai bukunya merupakan yang terbesar di Singapura. Kedai bukunya di No. 43, Sultan Road, Singapura menyediakan pelbagai bahan bacaan dari seluruh Alam Melayu. Pada 1898 sahaja, Hj. Muhammad Siraj telah mengiklankan 120 judul buku di kedainya untuk jualan dan ia mempunyai rangkaian ejen penjualan di Johor, Muar, Melaka, Pulau Pinang, Deli, Sandakan, Betawi, dan kemudiannya di Taiping dan Kinta. Untuk ulasan tentang katalog buku Hj. Muhammad Siraj yang diiklankan itu sila lihat Ian Proudfoot, "A nineteenth-century Malay bookseller's catalogue", Kekal Abadi 6.4, 1987, hlm. 1-11.

11 Terdapat percanggahan dalam laporan sirkulasi di Straits Settlements Government Gazette yang menyebutkan sirkulasi Al-Imam sebagai 5,000 naskhah dengan laporan Blue Book yang menyatakan sirkulasinya hanya 2,000 naskhah. Memandangkan sirkulasi majalah semasa dan selepasnya di samping sirkulasi akhbar, angka 5,000 naskhah mungkin tidak munasabah berbanding 2,000 naskhah.

12 Md. Sidin Ahmad Ishak mengesan bilangan kasar kedai buku pada 19211949 seperti berikut: Singapura (54 buah), Pulau Pinang (37 buah), Perak (20 buah), Selangor (19 buah), Johor (16 buah), Kedah (10 buah), Melaka (5 buah), Kelantan (4 buah), Borneo Utara (3 buah), Negeri Sembilan (6 buah), Pahang (2 buah), Terengganu (2 buah), dan sarawak (1 buah). Lihat Md. Sidin Ahmad Ishak, Penerbitan \& Percetakan Buku Melayu 1807-1960, Kuala Lumpur: Dewan Bahasa dan Pustaka, 1998, hlm. 276.

13 Pada akhir tahun pertama penerbitannya, Panduan Guru mendapat langganan sebanyak 258 naskhah dengan pelanggan terbesar ialah Persekutuan Guru Melayu (PGM) Selangor, 70 naskhah dan PGM Melaka 80 naskhah. Sirkulasi majalah tersebut hanya dikatakan mencapai lebih 300 naskhah. Lihat Ali Hj. Ahmad, "Muhamad Yusuf Ahmad and Majallah Guru", Tesis Ph. D, Universiti Monash, Australia, 1970, hlm. 65. Bagi akhbar Persahabatan (1936-37) umpamanya, daripada 1,200 naskhah yang 
dicetak hanya mendapat langganan sebanyak 83 orang dengan 79 orang melanggan tiga bulan, tiga orang melanggan enam bulan, dan hanya seorang melanggan setahun. Lihat Mariah Hj. Salleh, "Akhbar Persahabatan 1936-37: Satu Tinjauan", Latihan Ilmiah Sains Kemasyarakatan, Bangi: Universiti Kebangsaan Malaysia, 1976-77, hlm. 32-34.

The Malayan Post Office Guide and Telegraph Malaya, Kuala Lumpur: Government Printer, 1938, hlm. 12.

15 Al-Hedayah, Jun 1923, hlm. 3, umpamanya menyatakan:

"Tiap-tiap langganan disifatkan ialah satu daripada bantuan dan ialah yang dikehendaki didahulukan apakala hendak berahli langganan. Demikian jua harga naskhah, jika tiada didahulukan tiadalah dapat kita menyempurnakan permintaan itu." Majalah Malaya, Mei 1926 pula menyatakan: "Maka bagi tuan-tuan itu yang sudi berlanggan dengan Malaya haraplah kami supaya mengirimkan wang langganan sebanyak RM2 pada enam bulan (6 bilangan) sementara masa akan terbit bilangannya yang kedua kelak dan jika kami tiada menerima kiriman itu di dalam masa yang tersebut, maka tiadalah upaya rasanya Malaya akan meneruskan perlewatannya pada bilangan yang akan datang ini dan akan kali yang pertama ini haraplah kami akan dipandang sebagai hadiah yang ikhlas sahaja adanya."

Mujallah Al-Riwayat, 16 November 1938, hlm. 4.

Ar-Raja, 3 Julai 1928, hlm. 4.

Al-Hedayah, Ogos 1923.

Al-Hedayah, September 1923, hlm. 3.

Malaya, Mac 1928, hlm. 3.

Mujallah Guru, Julai 1933, hlm. 365.

Shorga Dunia, 1 Jun 1936, hlm. 5.

Dunia Sekarang, 28 Julai 1934.

Wakil penjual merupakan kedai-kedai buku yang dilantik oleh penerbit untuk menjualkan majalah di kawasan masing-masing. Wakil penjual bebas menjual majalah di mana-mana sahaja dan tidak mempunyai kawasan tertentu yang ditetapkan oleh penerbit. Penerbit akan mengirimkan naskhah majalahnya kepada wakil penjual dan memberikan potongan harga atau dalal kepada mereka untuk majalah yang terjual. Naskhah majalah yang tidak terjual boleh dipulangkan semula kepada penerbit dengan kos penghantaran ditanggung oleh wakil penjual. Wakil tunggal pula merupakan kedai buku khas yang dilantik oleh penerbit untuk mewakilinya di satu-satu lokasi, umpamanya di sesebuah negeri. Wakil ini akan kemudian mengedarkan majalah ke kedai-kedai buku lain mengikut struktur dalal yang ditetapkan. Lihat Ian Proudfoot, "A nineteenth-century Malay bookseller's catalogue", Kekal Abadi 6.4, 1987, hlm. 1-11. Juga lihat Hamedi M. Adnan, Majalah Melayu Sebelum Perang Dunia Kedua, Tanjong Malim: Institut Peradaban Melayu, 2014, hlm. 5-9. Tanah Melayu, 29 Januari 1934, hlm. 4.

Tanah Melayu, Ogos 1934, hlm. 5.

Hamedi M. Adnan. Dunia Majalah Melayu Selepas Perang: Editoral, Sirkulasi dan Iklan, Kuala Lumpur: Penerbit Unversiti Malaya, 2013, hlm. 86. 
28 Jasa, September 1929, hlm. 3.

29 Panduan, Disember 1934, hlm. 3.

30 Tanah Melayu, September 1934, hlm. 3.

31 Dunia Melayu, 14 Julai 1934, hlm. 5.

$32 \quad$ Langkahan Baru, Januari 1942, hlm. 3.

33 Dunia Sekarang, 21 Julai 1934, hlm. 5. 